This item was submitted to Loughborough's Research Repository by the author.

Items in Figshare are protected by copyright, with all rights reserved, unless otherwise indicated.

\title{
Anaerobic digestion of liquid products following hydrothermal carbonisation of faecal sludge at different reaction conditions
}

PLEASE CITE THE PUBLISHED VERSION

https://doi.org/10.5004/dwt.2017.20782

\section{PUBLISHER}

Desalination Publications

VERSION

AM (Accepted Manuscript)

\section{PUBLISHER STATEMENT}

This work is made available according to the conditions of the Creative Commons Attribution-NonCommercialNoDerivatives 4.0 International (CC BY-NC-ND 4.0) licence. Full details of this licence are available at: https://creativecommons.org/licenses/by-nc-nd/4.0/

\section{LICENCE}

CC BY-NC-ND 4.0

\section{REPOSITORY RECORD}

Nyktari, Eleni, Eric Danso-Boateng, Andrew D. Wheatley, and R.G. Holdich. 2017. "Anaerobic Digestion of Liquid Products Following Hydrothermal Carbonisation of Faecal Sludge at Different Reaction Conditions". figshare. https://hdl.handle.net/2134/27467. 


\title{
Anaerobic digestion of liquid products following hydrothermal carbonisation of faecal sludge at different reaction conditions
}

\author{
Eleni Nyktari ${ }^{\mathrm{a}, *}$, Eric Danso-Boateng ${ }^{\mathrm{a}}$, Andrew Wheatley ${ }^{\mathrm{b}}$, Richard Holdich ${ }^{\mathrm{a}}$ \\ ${ }^{a}$ Department of Chemical Engineering, Loughborough University, Loughborough LE11 3TU, UK, Tel. +44 (0)1509 222533 ; \\ emails:e.nyktari@lboro.ac.uk (E.Nyktari),e.danso-boateng@lboro.ac.uk (E. Danso-Boateng),r.g.holdich@lboro.ac.uk (R. Holdich) \\ ${ }^{b}$ School of Civil and Building Engineering, Loughborough University, Loughborough LE11 3TU, UK, Tel. +44 (0)1509 222637; \\ email: a.d.wheatley@lboro.ac.uk
}

Received 24 December 2016; Accepted 31 March 2017

\section{A B S T R A C T}

The hydrothermal carbonisation (HTC) conversion of wet wastes, such as sewage sludge, generates a carbon-rich material (called 'hydrochar'), and an aqueous fraction with a small release of gas. The liquid fraction is high in soluble chemical oxygen demand, from 10 to $50 \mathrm{~g} / \mathrm{L}$, and could not be discharged to the natural environment without treatment. This study investigates the anaerobic digestibility of this HTC liquid stream from different HTC temperatures and retention times $\left(140^{\circ} \mathrm{C}-200^{\circ} \mathrm{C}\right.$ for 30-240 $\mathrm{min}$ ). It is focused on biogas production in order to improve the energy input of the HTC process and to improve process sustainability. The results demonstrated that liquid products from the lower HTC temperatures gave better biogas production. The biogas yield from the $140^{\circ} \mathrm{C}$ HTC filtrate digestion was $0.45-0.86 \mathrm{~L} / \mathrm{L}$ reactor/d, while $0.33 \mathrm{~L} / \mathrm{L}$ reactor/d was obtained from $170^{\circ} \mathrm{C}$ and 0.31-0.45 L/L reactor/d from $180^{\circ} \mathrm{C}$ HTC filtrates. The lowest anaerobic digestion (AD) efficiency was recorded for the treatment from $200^{\circ} \mathrm{C}$ with biogas yield of $0.07 \mathrm{~L} / \mathrm{L}$ reactor/d. The data also show that low AD hydraulic retention time (HRT), typical of high rate fixed biomass digesters can be used to treat the HTC filtrate. Halving the AD HRT to $0.9 \mathrm{~d}$ resulted in 1.8-6.8 times greater biogas yield.

Keywords: Anaerobic digestion; Hydrothermal carbonisation; biogas; Sewage sludge; Wastewater treatment

\section{Introduction}

There has been renewed interest in thermal sewage sludge treatment due to the commercialisation of hydrothermal carbonisation (HTC), both to increase biogas yields in anaerobic digestion (AD) but also to generate a carbon-enriched char at temperatures above $160^{\circ} \mathrm{C}$ [1-3]. The higher temperature applied in HTC, compared with non-thermal traditional sludge and sewage treatment, sanitised and stabilised the products. Most studies on sewage sludge HTC have focused on the energy value of the hydrochar that is the main product $[4,5]$. The potential of its use for soil improvement [6,7] or as an adsorbent for soil remediation has been also reported

\footnotetext{
* Corresponding author.
}

$[8,9]$. However, to produce hydrochar with improved energy characteristics (high HHV), a higher temperature range is required [2]. This generates a high concentration of soluble organic compounds as leachate (a by-product), which requires further treatment (chemical oxygen demand [COD] $>20 \mathrm{~g} / \mathrm{L}$ ) and limited work has been carried out on this. Water plays an important role in HTC reaction as a solvent and depending on the reaction temperature, about $13 \%-66 \%$ of the carbon remains in the liquid fraction, which increases with increasing temperature $[2,10]$.

Recent work on thermal pre-treatment of sewage sludge followed by AD confirms that dewaterability and soluble organic matter increase as the HTC temperature increases (above $150^{\circ} \mathrm{C}$ ) [11]. The increase in solubilisation of organic solids, carbohydrates, proteins [12] and COD [13] leads to the 
increase in methane production during AD. Thus, hydrothermal treatment has been implemented successfully as a prestep to sewage treatment (Cambi, Biothelys ${ }^{\mathrm{TM}}$ ) $[14,15]$ as well as municipal solid waste treatments (Suzhou Food Waste Treatment Plant, Changchun Food Waste Treatment Plant, and Shenzhen Municipal Organic Waste Treatment Plant) [16]. Some literature, also suggests concurrent formation of refractory COD [17] at higher temperatures, mainly through Maillard reactions, reducing digestibility. Compounds such as furans, phenols, acetic acid, levulinic acid, and other persistent coloured soluble organic compounds have been reported in previous works $[2,6,18-20]$.

The liquid fraction is completely sterilised, but application of this organic-rich by-product has received comparatively little attention. AD of the HTC wastewater for methane production seems to be an ideal process to reduce the organic load, which could contribute to the energy sustainability of the HTC process for sewage sludge treatment $[1,10]$. However, studies on $\mathrm{AD}$ of the liquid product following HTC of sewage sludge for biogas or methane production are limited. Danso-Boateng et al. [2] reported potential methane yields from the liquid phase resulting from sewage sludge HTC, and suggested methane yield to decrease at higher HTC temperatures. However, in their study the liquid phase was not subjected to AD; instead, the total organic carbon (TOC) and COD concentrations of the liquid were used to estimate the theoretical yields of methane. Wirth et al. [3] conducted $\mathrm{AD}$ of the liquid product (called 'liquor') from sewage sludge HTC at mesophilic and thermophilic conditions in two identical continuously fed-batch reactors for 20 weeks. They found no significant difference between biogas production from mesophilic $\left(37^{\circ} \mathrm{C}\right)$ and thermophilic $\left(55^{\circ} \mathrm{C}\right)$ digestion of the HTC liquor. However, in their study the HTC conditions were constant $\left(220^{\circ} \mathrm{C}\right.$ for $\left.6 \mathrm{~h}\right)$, therefore, the effect of HTC temperature and reaction time on AD performance and methane yields were not investigated.

This study investigates the anaerobic treatment of the liquid phase generated from faecal sludge HTC at different temperatures ranging from $140^{\circ} \mathrm{C}$ to $200^{\circ} \mathrm{C}$ and retention times between 30 and $240 \mathrm{~min}$. The effect of HTC reaction conditions on biodegradability of the HTC liquid products and biogas yields after AD are studied. In addition, the effect of different AD hydraulic retention times (HRTs) on the performance was investigated.

\section{Materials and methods}

\subsection{Faecal sludge}

The faecal sludge used in this study was formulated according to the recipe of Wignarajah et al. [21], which comprised of $37.5 \%$ cellulose, $37.5 \%$ yeast, $20 \%$ peanut oil, $4 \% \mathrm{KCl}$ and $1 \% \mathrm{Ca}\left(\mathrm{H}_{2} \mathrm{PO}_{4}\right)$ in a suspension of $90 \%$ moisture (i.e., 10\% solids).

\subsection{HTC process}

A workshop designed and built rig was used for the HTC process. Approximately $4.5 \mathrm{~L}$ of faecal simulant was pumped into the reactor ( $5 \mathrm{~L}$ total reactor volume) and heated to temperatures between $140^{\circ} \mathrm{C}$ and $200^{\circ} \mathrm{C}$ (via an oil heater unit) under self-increasing pressure and maintained for residence times ranging from 30 to $240 \mathrm{~min}$. Following the hydrothermal treatment, the slurry was transferred into a flash tank where the pressure was reduced and the material was allowed to cool to room temperature. The carbonised material was then filtered using a $60-\mu \mathrm{m}$ slotted pore, stainless steel, filter under a slight residual pressure. This filtrate was used for the AD experiments. The operation cycles were pre-programmed using Lab View ${ }^{\circledR}$.

\subsection{Anaerobic digestion}

Two identical anaerobic fixed-film digesters (9 L working volume) were operated continuously at standard temperature $\left(37^{\circ} \mathrm{C}\right)$. An initial experiment with direct feeding of the raw waste led to digester instability, low conversion of COD to gas and finally acidic inhibition. Dilution by recycling was successfully used as a method to cope with the strong HTC filtrate. It was shown that a dilution ratio of (10:1) provided optimum buffering and recycling of nutrients. This was achieved by recycling part of the effluent from each digester back into the feed tank (as shown in Fig. 1). Recycle ratios of between 2 and 10:1 are widely used in higher rate digesters to buffer strong feeds and recycle trace nutrients. Bulk batches of feedstock including the recycle were prepared every $3 \mathrm{~d}$ (to include week-end running).

\subsection{Analytical methods}

The influent and effluent of the anaerobic reactors were analysed according to the APHA standard methods [22]. COD, total and soluble, was measured using a COD Analyser (Palintest 8000, Palintest Ltd, UK) at a wavelength of 570 $\mathrm{nm}$, following the procedure of Standard Methods 5220 D - closed reflux colorimetric method. TOC was determined using a TOC Analyser (DC-190, Rosemount Dohrmann, USA), in line with Standard Methods 5310 B - high temperature combustion. Total solids were determined according to Standard Methods $2540 \mathrm{~B}$ - total solids dried at $103^{\circ} \mathrm{C}-105^{\circ} \mathrm{C}$. According to Standard Methods 2540 E, volatile solids were determined by igniting the residue from the dry weight test to constant weight at $550^{\circ} \mathrm{C}$. Biochemical oxygen demand $\left(\mathrm{BOD}_{5}\right)$ was measured respirometrically using a BOD analyser (BODTrak II, HACH, USA) by the HACH Standard Method

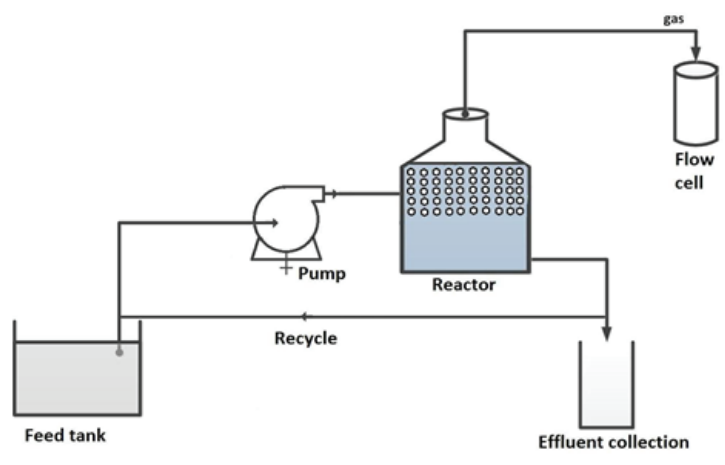

Fig. 1. Schematic of the anaerobic digestion process operated in a warm room $\left(37^{\circ} \mathrm{C}\right)$. 
procedure. Volatile fatty acids (VFA) were analysed using a spectrophotometer (DR3900, HACH LANGE, Germany) at a wavelength of $497 \mathrm{~nm}$, by following the HACH Method 10240 (LCK 365). pH was measured using a $\mathrm{pH}$ meter (METTLER DELTA 340, Mettler Toledo, The Netherlands). Ripley's ratio was determined using the partial to alkalinity ratio method [23]. The volume and composition of the biogas produced were monitored using a FLO CELL ${ }^{\mathrm{TM}}$ flow meter and a GMF 400 series infrared, respectively.

\section{Results and discussion}

\subsection{Analytical characteristics of the HTC filtrates}

The filtrate characteristics following HTC at different reaction temperatures and times are presented in Table 1. In order to investigate the increase of the biodegradability at lower temperatures, $140^{\circ} \mathrm{C}$ was chosen as the lowest temperature to ensure sterilised hydrochar and the filtrate $\left(>130^{\circ} \mathrm{C}\right.$ recommended autoclave temperature).

\subsection{Effect of $H T C$ reaction conditions on $A D$ performance}

Fig. 2 illustrates the COD removal and biogas production for filtrates processed at $140^{\circ} \mathrm{C}$ and $180^{\circ} \mathrm{C}$ for $30-240 \mathrm{~min}$, as averages from $40 \mathrm{~d}$ of continuous AD operation. Ripley's ratio was measured daily and during the whole duration of the experiments and it was monitored below 0.3, which indicates a stable AD operation. Increasing the HTC reaction time, increased the solubilisation of COD, increased the AD load, and gave better conversions of COD to biogas from HTC filtrates for up to $120 \mathrm{~min}$ at $140^{\circ} \mathrm{C}$ and up to $90 \mathrm{~min}$ at $180^{\circ} \mathrm{C}$. Further increased in the reaction time reduced the $\mathrm{AD}$ performance. TOC on the other hand was less affected by HTC conditions (Fig. 4).

The data in Fig. 2 indicate a lower performance at the higher temperature and additional experiments were conducted over a wider temperature range of $140^{\circ} \mathrm{C}-200^{\circ} \mathrm{C}$ and reaction times between 30 and $240 \mathrm{~min}$. These results are shown in Table 2 and Fig. 3. Fig. 3 suggests that the severity of conditions (temperature and reactor retention) affects biodegradability. Charing or blackening of the HTC solids was not observed at $140^{\circ} \mathrm{C}$ at any retention time tested but occurred at $180^{\circ} \mathrm{C}$ and above, after $30 \mathrm{~min}$, confirming the previous study that concluded the extent of carbonisation influenced treatability [2].

Methane percentage in the biogas yield was stable throughout the experiment ranging from $63.5 \%$ to $77.7 \%$. Typical percentage of methane after $\mathrm{AD}$ of organic solids and liquid waste is around $60 \%$. Stoichiometrically, $1 \mathrm{~kg}$ of COD releases about $15,625 \mathrm{~mol}$ of methane gas. Thus, $1 \mathrm{~kg}$ of COD produces $0.35 \mathrm{~m}^{3}$ or $0.25 \mathrm{~kg}$ of methane at STP regarding an
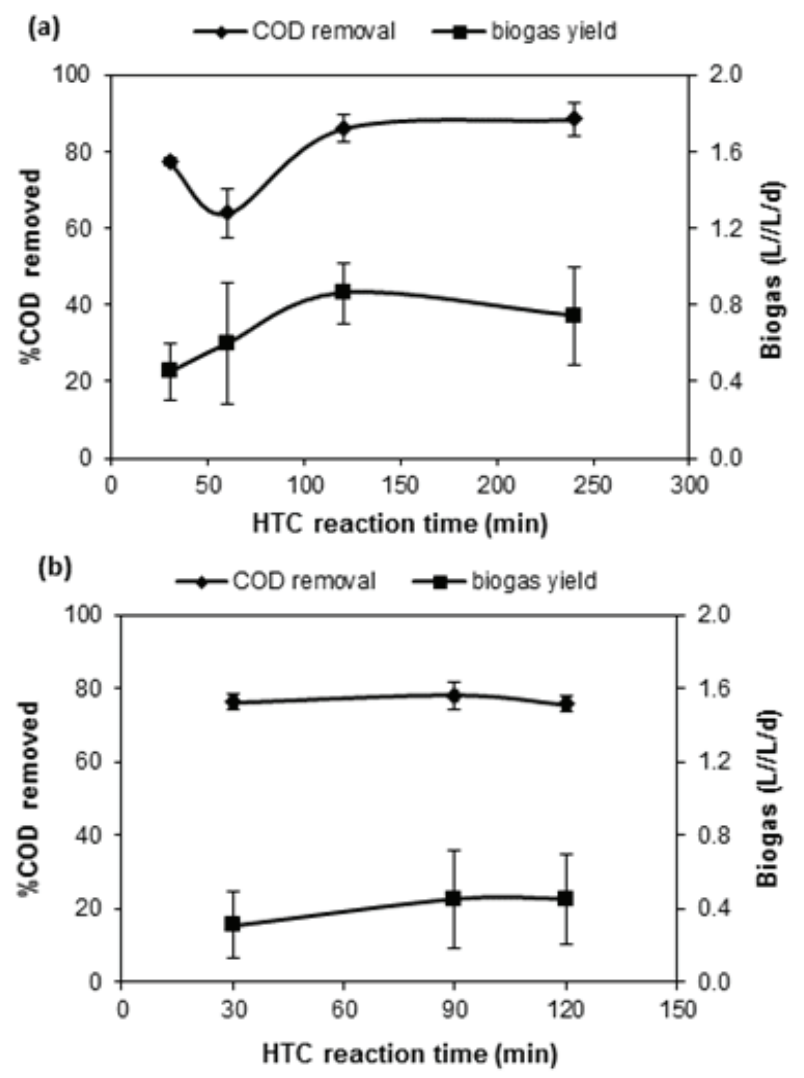

Fig. 2. Percentage of COD removed and the biogas produced for digestion of (a) $140^{\circ} \mathrm{C}$ and (b) $180^{\circ} \mathrm{C}$ HTC filtrate.

Table 1

Overview of the analytical characteristics of the HTC filtrate $(<60 \mu \mathrm{m})$ processed at $140^{\circ} \mathrm{C}-200^{\circ} \mathrm{C}$ for $30-240 \mathrm{~min}$

\begin{tabular}{|c|c|c|c|c|c|c|c|c|c|}
\hline \multirow{2}{*}{$\begin{array}{l}\text { HTC operating } \\
\text { conditions }\end{array}$} & \multicolumn{9}{|c|}{ Filtrate characteristics } \\
\hline & COD soluble (g/L) & COD total $(\mathrm{g} / \mathrm{L})$ & TOC $(\mathrm{g} / \mathrm{L})$ & TS (g/L) & TS (\%) & VS (g/L) & VS (\%) & $\mathrm{pH}$ & VFA $(g / L)$ \\
\hline $200^{\circ} \mathrm{C}, 30 \mathrm{~min}$ & 30.19 & 54.52 & 10.38 & 44.07 & 4.06 & 34.83 & 80.21 & 4.41 & 4.55 \\
\hline $180^{\circ} \mathrm{C}, 30 \mathrm{~min}$ & 27.19 & 47.53 & 8.70 & 18.65 & 1.88 & 15.11 & 20.98 & 5.06 & 2.14 \\
\hline $180^{\circ} \mathrm{C}, 90 \mathrm{~min}$ & 25.90 & 41.52 & 7.98 & 22.53 & 2.64 & 17.93 & 80.36 & 4.58 & 3.61 \\
\hline $180^{\circ} \mathrm{C}, 120 \mathrm{~min}$ & 30.07 & 43.27 & 10.89 & 24.52 & 1.94 & 20.10 & 82.01 & 4.59 & 3.89 \\
\hline $170^{\circ} \mathrm{C}, 60 \mathrm{~min}$ & 20.07 & 36.45 & 5.90 & 25.04 & 2.47 & 18.75 & 74.88 & 4.92 & 2.78 \\
\hline $140^{\circ} \mathrm{C}, 30 \mathrm{~min}$ & 19.95 & 33.67 & 6.78 & 26.60 & 2.66 & 20.89 & 78.28 & 6.91 & 3.23 \\
\hline $140^{\circ} \mathrm{C}, 60 \mathrm{~min}$ & 24.57 & 26.6 & 9.11 & 27.03 & 2.70 & 19.66 & 72.80 & 7.79 & 3.38 \\
\hline $140^{\circ} \mathrm{C}, 120 \mathrm{mi}$ & 30.99 & 97.63 & 8.92 & 24.85 & 2.49 & 18.78 & 75.60 & 5.06 & 2.96 \\
\hline $140^{\circ} \mathrm{C}, 240 \mathrm{~min}$ & 38.39 & 85.02 & 10.18 & 26.77 & 2.68 & 20.73 & 77.44 & 3.83 & 2.39 \\
\hline
\end{tabular}


Table 2

Overview of AD performance for HTC filtrates processed at different temperatures and reaction times

\begin{tabular}{llllllllll}
\hline HTC temperature & $140^{\circ} \mathrm{C}$ & & & & $170^{\circ} \mathrm{C}$ & & $180^{\circ} \mathrm{C}$ & \multicolumn{3}{c}{$200^{\circ} \mathrm{C}$} \\
\hline HTC time (min) & 30 & 60 & 120 & 240 & 60 & 30 & 90 & 120 & 30 \\
OLR (g COD/L/d) & 2.217 & 2.730 & 3.674 & 4.755 & 1.115 & 3.223 & 3.646 & 1.842 & 1.813 \\
COD removal (\%) & 77.3 & 64.0 & 85.9 & 88.4 & 58.2 & 76.3 & 78.0 & 75.8 & 62.0 \\
& $( \pm 0.979)$ & $( \pm 6.383)$ & $( \pm 3.517)$ & $( \pm 4.115)$ & $( \pm 12.942)$ & $( \pm 2.315)$ & $( \pm 3.844)$ & $( \pm 2.377)$ & $( \pm 6.066)$ \\
Biogas yield & 0.453 & 0.599 & 0.861 & 0.744 & 0.326 & 0.311 & 0.449 & 0.451 & 0.07 \\
$(\mathrm{~L}$ gas/L reactor/d) & $( \pm 0.148)$ & $( \pm 0.319)$ & $( \pm 0.155)$ & $( \pm 0.256)$ & $( \pm 0.231)$ & $( \pm 0.183)$ & $( \pm 0.264)$ & $( \pm 0.246)$ & $( \pm 0.079)$ \\
$\mathrm{CH}_{4}(\mathrm{~L} / \mathrm{g}$ COD & 0.197 & 0.269 & 0.203 & 0.132 & 0.376 & 0.094 & 0.118 & 0.118 & 0.045 \\
removed) & $( \pm 0.015)$ & $( \pm 0.015)$ & $( \pm 0.016)$ & $( \pm 0.012)$ & $( \pm 0.0 .17)$ & $( \pm 0.008)$ & $( \pm 0.007)$ & $( \pm 0.015)$ & $( \pm 0.001)$ \\
$\mathrm{COD}$ effluent $(\mathrm{g} / \mathrm{L})$ & 4.52 & 9.60 & 4.56 & 4.89 & 8.41 & 6.88 & 7.20 & 7.27 & 11.83 \\
\hline
\end{tabular}

Note: Numbers in parenthesis represent the standard deviations.
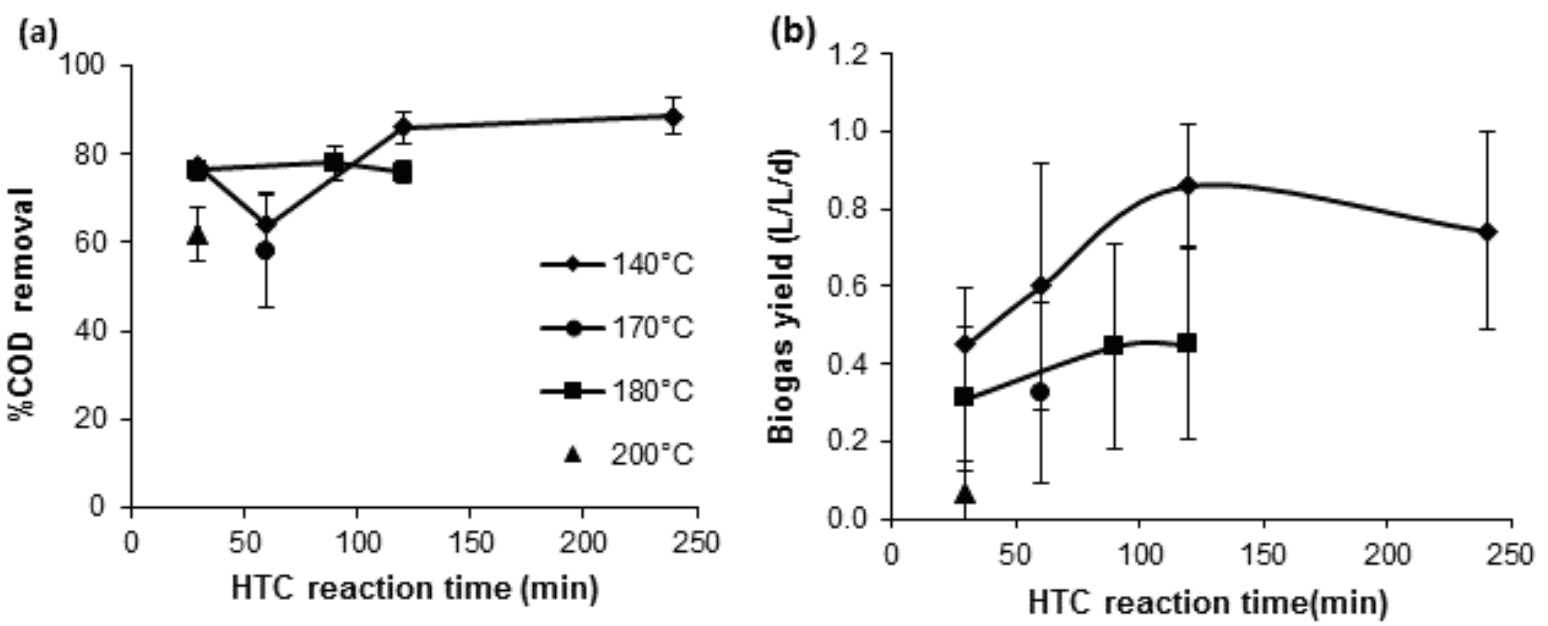

AQ3 Fig. 3. Results of (a) COD removal and (b) biogas yield, during AD treatment of $\mathrm{HTC}$ effluent carbonised at $140^{\circ} \mathrm{C}-200^{\circ} \mathrm{C}$ for $30-240 \mathrm{~min}$.

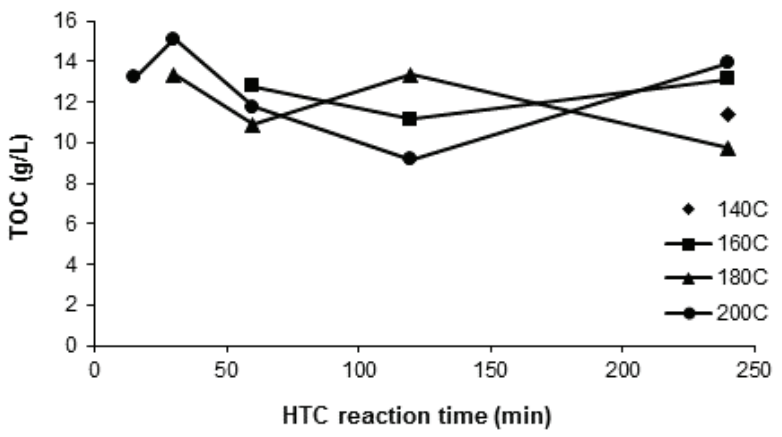

Fig. 4. Total organic carbon (TOC) of liquid filtrates after $140^{\circ} \mathrm{C}-200^{\circ} \mathrm{C}$ and $30-240$ min HTC treatment.

ideal substrate as acetate [24]. STP corrected yields from the $140^{\circ} \mathrm{C}$ HTC filtrate digestion were between 0.132 and $0.269 \mathrm{~L}$ $\mathrm{CH}_{4} / \mathrm{g}$ COD removed and $0.094-0.118 \mathrm{~L} \mathrm{CH}_{4} / \mathrm{g}$ COD removed for the filtrate at $180^{\circ} \mathrm{C}$. The lowest $\mathrm{AD}$ efficiency was recorded from $\mathrm{HTC}$ treatment at $200^{\circ} \mathrm{C}$ with the biogas yield of $0.045 \mathrm{~L} \mathrm{CH}_{4} / \mathrm{g}$ COD removed. Thus, it can be suggested that HTC treatment at lower temperatures affects positively the production of biogas during the $\mathrm{AD}$ of the liquor. The lower biogas yields obtained at higher temperatures could be attributed to the formation of refractory COD [17] and less degradable organic compounds through Maillard reaction product in the liquid fraction [2] at these conditions.

Wirth et al. [3] conducted AD experiments of liquid product (liquor) produced from HTC sewage sludge treated at $200^{\circ} \mathrm{C}$ for $6 \mathrm{~h}$ and reported methane yields in the range of 0.144-0.178 $\mathrm{L} \mathrm{CH}_{4} / \mathrm{g}$ COD for different organic loading rates (OLRs) between 1 and $5 \mathrm{~g} / \mathrm{L}$. However, in their study the HTC conditions did not vary. Also, the feedstock in this study reported was a simulant; hence, the performance differences are expected.

The reduction in biodegradability with increased HTC temperature was supported by both BOD and respiration rate measurements shown in Figs. 5(a) and (b). These two indicators show the same tendency as biogas yields. With the increase in HTC temperature a decreased in the respiration rate and the BOD occurs. Standard biological methane 
potential tests were also used but gave poor reproducibility compared with respiration rates and were abandoned.

Methanogenesis is the rate limiting step of AD of soluble substrates by the previous research using similar kind of feedstock [3]. The Chapman model [25] was used to determine the kinetic constants for the methane production (Eq. (1), Table 3).

$\mathrm{Y} \mathrm{CH}_{4}=\mathrm{YCH}_{4} \max \times\left(1-\exp ^{1-\mathrm{km} \times \mathrm{t}}\right)^{c}$
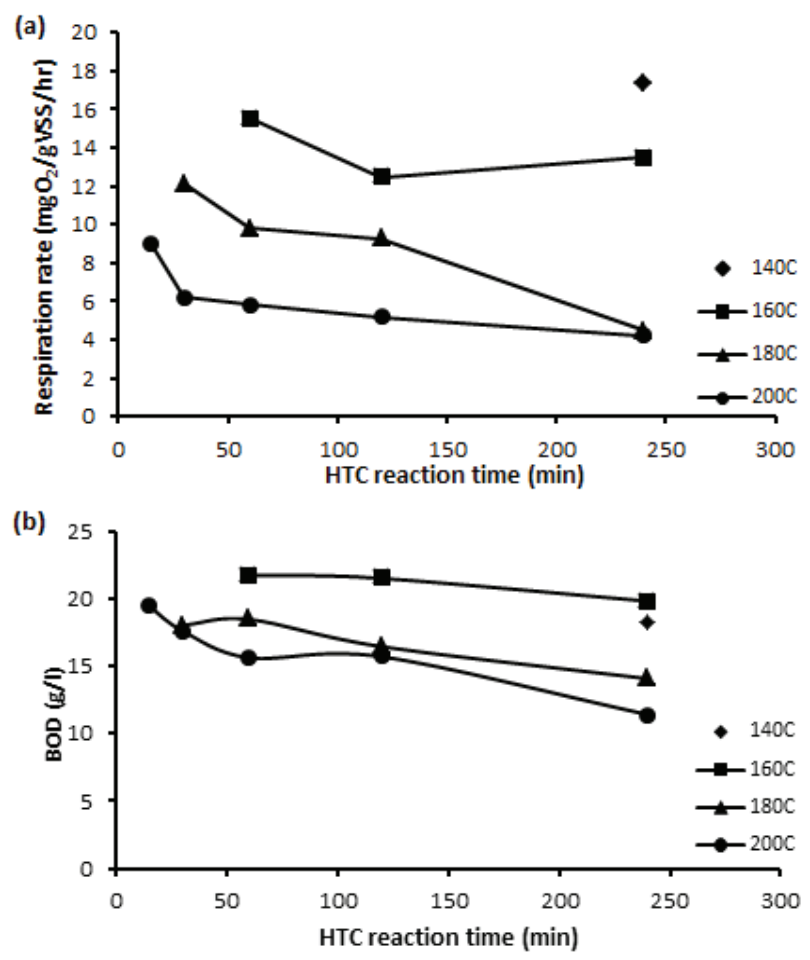

Fig. 5. (a) Respiration rate and (b) BOD of liquid filtrates after HTC treatment at $140^{\circ} \mathrm{C}-200^{\circ} \mathrm{C}$ and $30-240 \mathrm{~min}$.

Table 3

Methanogenesis constants for each HTC filtrate

\begin{tabular}{lcl}
\hline $\begin{array}{l}\text { HTC temperature } \\
\left({ }^{\circ} \mathrm{C}\right)\end{array}$ & $\begin{array}{l}\text { HTC time } \\
(\mathrm{min})\end{array}$ & $\begin{array}{l}\text { Methane production } \\
\text { constant }\left(k_{m}\right)\end{array}$ \\
\hline 140 & 30 & $6.96 \times 10^{-4}$ \\
& 60 & $1.01 \times 10^{-2}$ \\
& 120 & $9.46 \times 10^{-3}$ \\
& 240 & $6.70 \times 10^{-2}$ \\
170 & 60 & $1.59 \times 10^{-4}$ \\
180 & 30 & $3.27 \times 10^{-2}$ \\
& 90 & $2.35 \times 10^{-7}$ \\
& 120 & $1.37 \times 10^{-7}$ \\
200 & 30 & $8.92 \times 10^{-8}$ \\
\hline
\end{tabular}

As the treating HTC temperature rises the methanogenesis became slower except for the filtrate from $\mathrm{HTC}$ at $180^{\circ} \mathrm{C}$ for 30 min which showed a much higher constant compared with that of $170^{\circ} \mathrm{C}$ filtrate and those from longer HTC treatment at the same temperature. Writh et al. [3] reported a kinetic constant of 0.044 whereas an ideal substrate as the acetate is expected to produce methanogenesis constants in the range of 0.2-0.7 [26]. Moestedt et al. [27], however, reported methanogenesis constants between 0.02 and 0.09 during AD of food, slaughterhouse waste and glycerin considered as high biodegradable substrate.

The COD concentrations in the effluent of the digesters range between 4.52 and $11.83 \mathrm{~g}$ COD/L according to the different filtrates. The percentage of COD removed was typical of $\mathrm{AD}$ and stable throughout the operation as judged by the standard deviations (Table 2). However, the organic load in the final effluent was still high and further treatment would be needed if disposal to the environment is to be considered. Recycling the effluent back to the head of the treatment works has been commonly used but may cause problems if the refractory COD was to accumulate.

The COD removal equivalent to the methane production was calculated using the theoretical relation (for a perfect substrate) mentioned previously ( $1 \mathrm{~g}$ COD consumed produces $0.35 \mathrm{~L}$ of methane) and this was compared with the percentage of COD removed calculated based on the soluble effluent in Table 2. Only $19.5 \%-47.2 \%$ of the COD was converted to methane (Fig. 6) although the COD conversion based on the soluble effluent was a lot higher (58.2\%-88.4\%). This can be referred to the microbial growth and the accumulation of solids in the AF digesters. It can be suggested that some COD removal may be from coagulation with the biofilms but this need more extensive data. The low biogas measurements reported (most in the range of 1-3 L) were at the accuracy limits of the instrumentation, but other non-analysed components, e.g., hydrogen and VOC could have contributed to the overall mass balance.

\subsection{Effect of the hydraulic retention time on the efficiency of the anaerobic digestion}

Two AD HRTs of 1.8 and $0.9 \mathrm{~d}$ were tested. The main difference was observed for the biogas production (Table 4). Decreasing the HRT by increasing the flow rate and OLR

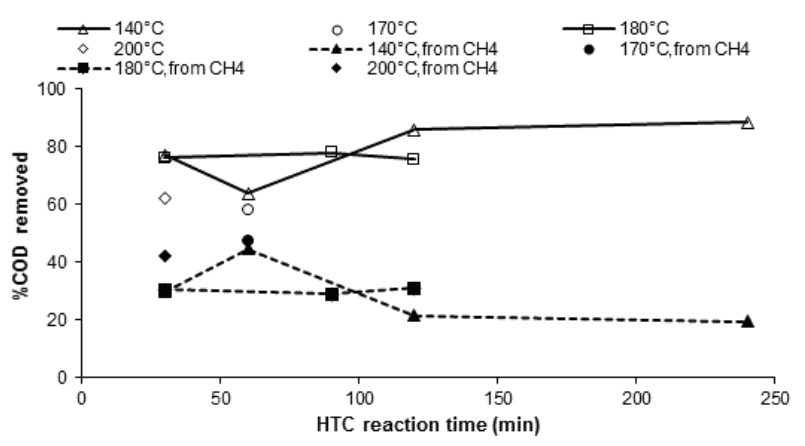

Fig. 6. Comparison of measured COD removal calculated based on dissolved COD in the effluent and theory, based on the methane production. 
Table 4

Biogas production after AD of different HTC conditions filtrates under two HRT times

\begin{tabular}{|c|c|c|c|c|c|}
\hline \multirow[t]{2}{*}{ HTC temperature $\left({ }^{\circ} \mathrm{C}\right)$} & \multirow[t]{2}{*}{ HTC time (min) } & \multicolumn{2}{|c|}{ Biogas yield (L/L reactor/d) } & \multicolumn{2}{|c|}{ COD removal (\%) } \\
\hline & & $\mathrm{HRT}=1.8 \mathrm{~d}$ & $\mathrm{HRT}=0.9 \mathrm{~d}$ & $\mathrm{HRT}=1.8 \mathrm{~d}$ & $\mathrm{HRT}=0.9 \mathrm{~d}$ \\
\hline \multirow[t]{4}{*}{140} & 30 & 0.250 & 0.453 & 73.9 & 77.3 \\
\hline & 60 & 0.089 & 0.599 & 55.3 & 64.0 \\
\hline & 120 & 0.215 & 0.861 & 90.3 & 85.9 \\
\hline & 240 & 0.197 & 0.744 & 92.2 & 88.4 \\
\hline 180 & 30 & 0.089 & 0.310 & 75.1 & 76.3 \\
\hline
\end{tabular}

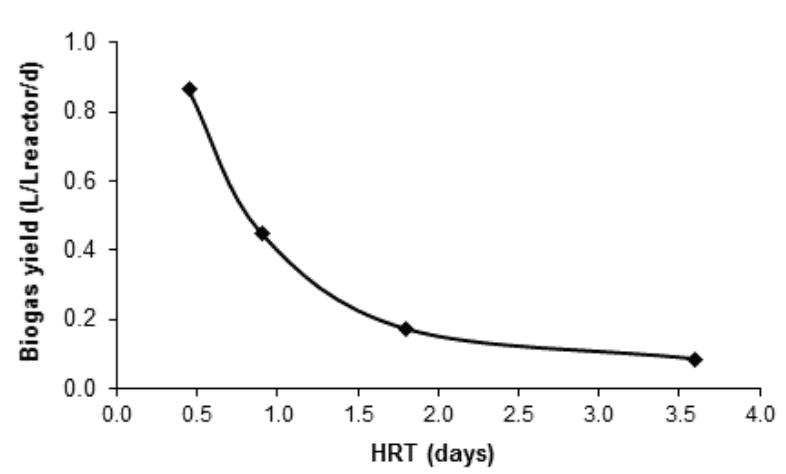

Fig. 7. Biogas yield during AD treatment of HTC effluent at $180^{\circ} \mathrm{C}$ for 90 min with $\mathrm{AD}$ hydraulic retention times of $0.45-3.6 \mathrm{~d}$.

improves the performance. The yield was more than double for the lower retention time $(0.9 \mathrm{~d})$ in all the experiments. Specifically, when the lower HRT was applied the biogas produced was 1.8-6.8 times greater. This is supported by the literature on biomass retaining reactors which have a typical retention time of $5-10 \mathrm{~h}$ and loading rates up to $40 \mathrm{~kg} \mathrm{COD} / \mathrm{m}^{3} / \mathrm{d}$ for the highly treatable wastes [28]. Further work is needed to identify the maximum load.

Additional AD HRT experiments were carried out on filtrate from the $\mathrm{HTC}$ run at $180^{\circ} \mathrm{C}$ for $90 \mathrm{~min}$, since obvious char was produced at this temperature but not at $140^{\circ} \mathrm{C}$. The data are shown in Fig. 7. Gas yields at $0.45 \mathrm{~d}$ are similar to those achieved at $140^{\circ} \mathrm{C}$ and suggest that char production without prejudicing the treatability of the filtrate could be possible.

\section{Conclusions}

The liquid products following HTC of sewage sludge can be digested anaerobically to produce biogas. The results demonstrated that liquids generated from HTC at lower temperatures produced higher biogas yields, with $\mathrm{HTC}$ at $140^{\circ} \mathrm{C}$ and a shorter HRT of $0.9 \mathrm{~d}$ resulting in maximum yields. Liquids obtained from $\mathrm{HTC}$ at $180^{\circ} \mathrm{C}$ for $30 \mathrm{~min}$ also resulted in high biogas yield when the HRT was shorter (0.9 d), which could be considered as the optimal conditions as dewatering of the products was easier at these HTC conditions than lower temperatures. For liquids from $\mathrm{HTC}$ at $140^{\circ} \mathrm{C}$ up $120 \mathrm{~min}$ residence time and $180^{\circ} \mathrm{C}$ for $90 \mathrm{~min}$, increasing the HTC reaction time resulted in an increased in COD solubilisation, increased in $\mathrm{AD}$ load and a better conversion of COD to biogas. The results show that low AD HRT, typical of high rate fixed biomass digesters can be used to treat the HTC liquid from sewage sludge. Levels of COD in the digester effluent were still high, indicating further treatment is required if the option is to dispose it to the environment.

\section{Acknowledgement}

The authors gratefully acknowledge the support of the Gates Foundation who funded this work through the Reinvent the toilet program.

\section{References}

[1] B. Wirth, J. Mumme, B. Erlach, Anaerobic Treatment of Wastewater Derived from Hydrothermal Carbonization, Proc. 20th European Biomass Conference and Exhibition, Milan, Italy, 2012, pp. 683-692.

[2] E. Danso-Boateng, G. Shama, A.D. Wheatley, S.J. Martin, R.G. Holdich, Hydrothermal carbonisation of sewage sludge: effect of process conditions on product characteristics and methane production, Bioresour. Technol., 177 (2015) 318-327.

[3] B. Wirth, T. Reza, J. Mumme, Influence of digestion temperature and organic loading rate on the continuous anaerobic treatment of process liquor from hydrothermal carbonization of sewage sludge, Bioresour. Technol., 198 (2016) 215-222.

[4] C. He, A. Giannis, J. Wang, Conversion of sewage sludge to clean solid fuel using hydrothermal carbonization: hydrochar fuel characteristics and combustion behavior, Appl. Energy, 111 (2013) 257-266.

[5] P. Zhao, Y. Shen, S. Ge, K. Yoshikawa, Energy recycling from sewage sludge by producing solid biofuel with hydrothermal carbonization, Energy Convers. Manage., 78 (2014) 815-821.

[6] N.D. Berge, K.S. Ro, J. Mao, J.R.V. Flora, M.A. Chappell, S. Bae, Hydrothermal carbonization of municipal waste streams, Environ. Sci. Technol., 45 (2011) 5696-5703.

[7] J.A. Libra, K.S. Ro, C. Kammann, A. Funke, N. Berge, Y. Neubauer, et al., Hydrothermal carbonization of biomass residuals: a comparative review of the chemistry, processes and applications of wet and dry pyrolysis, Biofuels, 2 (2011) 71-106.

[8] K. Sun, K. Ro, M. Guo, J. Novak, H. Mashayekhi, B. Xing, Sorption of bisphenol A, $17 \alpha$-ethinyl estradiol and phenanthrene on thermally and hydrothermally produced biochars, Bioresour. Technol., 102 (2011) 5757-5763.

[9] M. Mihajlović, J. Petrović, M. Stojanović, J. Milojković, Z. Lopičić, M. Koprivica, C. Lačnjevac, Hydrochars, perspective adsorbents of heavy metals: a review of the current state of studies, Zastita Materijala, 57 (2016) 488-495.

[10] E. Danso-Boateng, R.G. Holdich, G. Shama, A.D. Wheatley, M. Sohail, S.J. Martin, Kinetics of faecal biomass hydrothermal carbonisation for hydrochar production, Appl. Energy, 111 (2013) 351-357. 
[11] R.A. Fisher, S.J. Swanwick, High-temperature treatment of sewage sludges, Water Pollut. Control, 71 (1971) 355-370.

[12] C. Bougrier, J.P. Delgenès, H. Carrère, Impact of thermal pretreatments on the semi-continuous anaerobic digestion of waste activated sludge, Biochem. Eng. J., 34 (2007) 20-27.

[13] V. Penaud, J.P. Delgenès, R. Moletta, Thermo-chemical pretreatment of a microbial biomass: influence of sodium hydroxide addition on solubilization and anaerobic biodegradability, Enzyme Microb. Technol., 25 (1999) 258-263.

[14] J. Chauzy, D. Cretenot, L. Patria, P. Fernandez, P. Sauvegrain, J.P. Levasseur, Bio Thelys: A New Sludge Reduction Process, Biosolids, Wastewater Sludge as a Resource, Trondheim, 2003, pp. $473-479$.

[15] U. Kepp, I. Machenbach, N. Weisz, O.E. Solheim, Enhanced stabilization of sewage sludge through thermal hydrolysis - three years of experience with full scale plant, Water Sci. Technol., 42 (2000) 89-96.

[16] S. Xu, H. He, L. Luo, Status and Prospects of Municipal Solid Waste to Energy Technologies in China, O.P. Karthikeyan, et al., Eds., Recycling of Solid Waste for Biofuels and Bio-chemicals, Environmental Footprints and Eco-design of Products and Processes, 2016, pp. 31-54.

[17] M. Goto, R. Obuchi, T. Hirose, T. Sakaki, M. Shibata, Hydrothermal conversion of municipal organic waste into resources, Bioresour. Technol., 93 (2004) 279-284.

[18] Z. Shen, J. Zhou, X. Zhou, Y. Zhang, The production of acetic acid from microalgae under hydrothermal condition, Appl. Energy, 88 (2011) 3444-3447.

[19] Q. Wang, H. Li, L. Chen, X. Huang, Monodispersed hard carbon spherules with uniform nanopores, Carbon, 39 (2001) 2211-2214.

[20] E. Danso-Boateng, R.G. Holdich, S.J. Martin, G. Shama, A.D. Wheatley, Process energetics for the hydrothermal carbonisation of human faecal wastes, Energy Convers. Manage., 105 (2015) $1115-1124$.

[21] K. Wignarajah, E. Litwiller, J. Fisher, J. Hogan, Simulated human feces for testing human waste processing technologies in space systems, Int. Conf. Environ. Syst., 724 (2006) 424-429.

[22] APHA, Standard Methods for the Examination of Water and Wastewater, 21st ed., American Public Health Association, American Water Works Association, Water Environment Federation, Washington, D.C., USA, 2012.

[23] L. Ripley, W. Boyle, J. Converse, Improved alkalimetric monitoring for anaerobic digestion of high-strength wastes, J. Water Pollut. Control Fed, 58 (1986) 406-411.

[24] SK. Khanal, Anaerobic Biotechnology for Bioenergy Production Anaerobic Biotechnology for Bioenergy Production, WileyBlackwell Publication, 2008.

[25] M. Pohl, J. Mumme, K. Heeg, E. Nettmann, Thermo- and mesophilic anaerobic digestion of wheat straw by the upflow anaerobic solid-state (UASS) process, Bioresour. Technol., 124 (2012) 321-327.

[26] S. Fukuzaki, N. Nishio, S. Nagai, Kinetics of the methanogenic fermentation of acetate, Appl. Environ. Microbiol., 56 (1990) 3158-3163.

[27] J. Moestedt, J. Malmborg, E. Nordell, Determination of methane and carbon dioxide formation rate constants for semi-continuously fed anaerobic digesters, Energies, 8 (2015) $645-655$.

[28] M.X. Zheng, K.J. Wang, J.E. Zuo, Z. Yan, H. Fang, J.W. Yu, Flow pattern analysis of a full-scale expanded granular sludge bedtype reactor under different organic loading rates, Bioresour. Technol., 107 (2012) 33-40. 
